\title{
Improving Parenting to Promote School Readiness: A Preliminary Evaluation of the Books Can... Public Library Program
}

\author{
Michelle Taylor ${ }^{1}$, Megan E Pratt ${ }^{2}$, Larissa M Gaias ${ }^{3}$, Lauren van Huisstede ${ }^{4}$, Diana E Gal-Szabo ${ }^{5}$ \\ ${ }^{1}$ California State University, Long Beach, Department of Family and Consumer Sciences, Child Development and Family \\ Studies, USA \\ ${ }^{2}$ Hallie E. Ford Center for Healthy Children \& Families, Oregon State University, USA \\ ${ }^{3}$ University of Washington, School Mental Health Assessment, Research, and Training Center, USA \\ ${ }^{4}$ Arizona State University, Mary Lou Fulton Teachers College, USA \\ ${ }^{5}$ Arizona State University, T. Denny Sanford School of Social and Family Dynamics, USA \\ Correspondence: Michelle Taylor, California State University, Long Beach, Department of Family and Consumer \\ Sciences, Child Development and Family Studies, USA.
}

Received: September 26, 2019

Accepted: January 7. 2020

Online Published: January 18, 2020

doi:10.11114/jets.v8i2.4544

URL: https://doi.org/10.11114/jets.v8i2.4544

\begin{abstract}
The present study examines associations between parents' involvement in an enhanced storytime program and parenting knowledge and efficacy for supporting their child's socioemotional development and book reading. Books Can... ${ }^{\circ}$ was developed by a public library to teach parents important child development information and strategies for supporting their child's socioemotional learning. Parents and their young children participated in a 6-week interactive program that included book reading, songs, interactive activities, and parenting tips. Parents $(\mathrm{n}=119)$ completed questionnaires both prior to and after participating in the program. Multilevel general linear models compared responses to survey items before and after the program, indicating significant increases in parent knowledge, attitudes, and reading behavior by the end of the program. This study provides preliminary support documenting the benefits of the Books Can... ${ }^{\circ}$ program. Moreover, results highlight public libraries and enhanced storytime programs as meaningful settings for promoting family involvement in children's early learning.
\end{abstract}

Keywords: public library, parent education, early learning, informal learning, family engagement

\section{Introduction}

\subsection{Introduction}

Ensuring all children enter kindergarten ready to learn continues to be a goal of early childhood educators, researchers, and policy makers alike (Bierman, Nix, Greenberg, Blair, \& Domitrovich, 2008; Copple, \& Bredekamp, 2009). Yet, teachers report nationally that just under half of students enter kindergarten with the social and behavioral skills they need to engage in learning (Bernstein, West, Newsham, \& Reid, 2014). Intervention efforts to support school readiness have largely taken place within home and school settings, with less emphasis on strengthening the connection between families and community settings. However, research conducted on family and community involvement suggests that informal learning settings play a central role in families' lives (Callanan, Castañeda, Luce, \& Martin, 2017; Henderson \& Mapp, 2002). One way that community settings can support parenting skills that promote early socioemotional development is through interactive parent-child programming (Lopez, Caspe, \& McWilliams, 2016; Taylor, Pratt, van Huisstede, \& Gaias, 2016). However, there remains a dearth of research on the effectiveness of such programming in informal community settings. Thus, the present study examines the degree to which a public library's enhanced storytime program is associated with improved parent knowledge, attitudes, and reading behavior.

\subsection{Socioemotional Development and Parenting}

Children's early socioemotional (SE) development promotes future academic and social school success (Raver, 2004; Webster-Stratton, Reid, \& Hammond, 2004; Webster-Stratton, Reid, \& Stoolmiller, 2008; Zins, Bloodworth, Weissberg, $\&$ Walberg, 2004). SE development encompasses emotion knowledge and aspects of self-regulation (e.g., emotional, 
behavioral) (Denham et al., 2003; Trentacosta \& Izard, 2007). Indeed, children who begin kindergarten with higher SE skills tend to like school, effectively participate in the classroom, and demonstrate strong academic achievement (Birch \& Ladd, 1997; Johnson, Ironsmith, Snow, \& Poteat, 2000; Valiente et al., 2011). In contrast, when children struggle with SE skills, they are at risk for concurrent and long-term maladjustment and academic problems (Denham, Zahn-Waxler, Cummings, \& Iannotti, 1991; Robins \& Rutter, 1990).

Parents' ability to foster warm and responsive interactions with their children (Hoff, Laursen, \& Tardiff, 2002), while providing skilled guidance (e.g., scaffolding; Bernier, Carlson, \& Whipple, 2010), plays an important role in supporting children's SE development. Yet, many parents are in need of developmental and parenting information to better support their children's development. Indeed, many parents are unclear about how SE abilities develop in young children. For example, a national survey found that only $39 \%$ of parents correctly believe that infants are able to recognize and respond to emotion expressions in others by six months of age (Lerner \& Nightingale, 2016). In light of this need, informal community-based institutions (e.g., libraries, museums, zoos) are well positioned to teach parents skills and information critical to promoting children's SE development in a non-stigmatizing way.

\subsection{Promoting Parenting in Public Libraries}

Informal community-based learning settings inherently promote joint parent-child engagement through hands on activities, making them prime locations to support the knowledge and skills necessary for parents to support early learning. One setting that holds great potential for supporting parenting is the public library (PL; Taylor et al., 2016). PLs are unique from other informal learning institutions because of their reputation as community anchors that provide access to trustworthy, free information (Feinberg, Kuchner, \& Feldman, 1998). Further, PLs are expanding their role beyond traditional, book-lending, services to offer a variety of programs and classes for diverse audiences (IMLS, 2013). One area of great growth has been in storytime offerings for young children (Ash \& Meyers, 2009). Recognizing the untapped potential of traditional storytimes, which focus on engaging the child, some PLs have begun to offer enhanced storytime (EST) programs that add an explicit parent component.

EST programs are storytime sessions that engage children through interactive books, songs, and activities, while simultaneously teaching parents child development information and parenting skills (Ash \& Meyers, 2009). Preliminary effectiveness studies of such programming suggest positive outcomes for parents (Byington et al., 2008; Stewart, BaileyWhite, Shaw, Compton, \& Ghoting, 2014). One example of such programming is a national initiative called Every Child Ready to Read@your library® (ECRR). Born out of a federal partnership among PL constituents and developmental experts, ECRR curriculum seeks to strengthen parents' literacy effectiveness by pausing during storytime sessions to teach parents evidence-based reading strategies (Ash \& Meyers, 2009). Indeed, initial evaluation evidence suggests that participating parents successfully adopted these reading strategies at home (Stewart et al., 2014).

The majority of EST programming focuses on promoting early literacy parenting skills (Ash \& Meyers, 2009; Campana et al., 2016; Meyers \& Henderson, 2007). However, many PLs are broadening their focus to other school readiness domains (IMLS, 2013). The present study focuses on one library-developed program focused on SE development: Books Can... (City of Scottsdale, 2011) leverages traditional storytime activities to explicitly teach parents about SE development and how to promote these skills in their young children. In line with the goals of PLs as literacy hubs and research highlighting the importance of parent-child communication during book reading for children's SE development, books are used as tools for promoting SE development and literacy (Laible, 2004). The program also draws on evidenceinformed strategies for parent education and best practices in early childhood education. For example, the program is aligned with common tenants of traditional parent education programming: starting early in the child's life, focusing on family strengths, involving both the parent and child, and teaching optimal parenting strategies (Kaminski, Valle, Filene, \& Boyle, 2008; Morris et al., 2017). Further, the programs' emphasis on hands-on, interactive activities encourages parents to follow their child's lead and scaffold learning during play draws from quality early childhood education strategies (Copple, \& Bredekamp, 2009).

\subsection{The Current Study}

The current study is a preliminary evaluation of Books Can... ${ }^{\circ}$, an EST program delivered by the public library. Utilizing a pre- post-design, changes in parent outcomes were assessed, including parent knowledge, attitudes, and reading behaviors. Specifically, we hypothesized that after participating in the program, parents would demonstrate a greater understanding of their child's SE development, endorse more child-centered attitudes, feel more confident in their parenting, and report more developmentally-appropriate reading behaviors at home.

\section{Method}

\subsection{Participants}

A total of 119 families participated in the Books Can... ${ }^{\odot}$ evaluation study. The majority of caregivers were mothers 
(83.2\%); the rest were fathers $(5 \%)$ grandmothers $(2.5 \%)$, or other caregivers, like nannies $(8.4 \%)$. For simplicity, the word parent will be used to talk about any caregiver in the results. On average, children were two years old (range $=$ three months - five years; 63\% female). Most families reported speaking English (88.2\%), 19.3\% reported speaking Spanish, and $15.1 \%$ reported speaking another language in the home. Most parents $(94.12 \%)$ completed the questionnaire in English, while (5\%) completed it in Spanish. In terms of race/ethnicity, $62.2 \%$ parents identified as white, $21 \%$ Hispanic, 7.6\% East Asian, 7.6\% Asian Indian, and 5.8\% Black, Middle Eastern, or Native American. Most families reported little economic hardship (e.g., experiencing poor housing or not having enough food [7.6\%]; going without their basic needs met [11.2\%]; ending up very short of money at the end of the month [6.0\%]). A third of the sample (35\%) reported that their child spends at least five hours a week in child care.

\subsection{Data Collection Procedures}

Data were collected in conjunction with the administration of regularly scheduled PL programming. The programs were offered in fall 2015, as well as winter and spring 2016. During each season, two libraries and one community center offered the Books Can... ${ }^{\circ}$ program.

Participants were recruited into the study after registering online for the program. Once registered, parents were sent an invitation email to participate in the study along with a link to the consent form and pre-survey that included demographics. During week 1 of the program, parents were also invited to participate in-person with the option of completing the consent and pre-survey on paper or online. No pre-surveys were collected after Week 2 of the program. Researchers attended the final week of the program to collect post-surveys in-person from participating families; if the survey was not completed then, families were emailed and asked to complete the online version. To encourage high levels of participation an incentive (i.e., small backpack with SE toys) was given to those who attended at least five of six sessions.

\subsection{The Program}

Books Can... ${ }^{\circ}$ is an EST program for families with $0-5$ year-old children. The curriculum is aligned with both the state of Arizona's infant and toddler guidelines (First Things First \& Arizona Department of Education, n.d.) and early learning standards for social emotional development (Arizona Department of Education, 2013). The program aims to improve parenting knowledge, attitudes, and behavior known to promote children's school readiness and literacy skills. Trained library staff lead each of six, 45-minute sessions. Each session covers an SE topic, including: attachment, recognizing and labeling emotions, self-awareness, self-regulation, relationships, and effective praise. All sessions follow a similar format, with an introduction to the week's topic, parenting tips, interactive activities, book reading, active songs, and yoga. In addition to pausing to talk directly to parents about parenting and development, the instructors also model quality interactions with children, and provide activity time for parents to immediately practice these new skills. After each session, children are given a book, and parents are given a tip sheet to extend learning at home.

\subsection{Measures}

Program SE Questionnaire. Parents completed the 16-item, investigator-developed Books Can Questionnaire: BCQ (Taylor \& Pratt, unpublished), which captures distinct knowledge, attitudes, and reading behavior expected to change through participation in the program. Statements were measured on a 5 -point scale, ranging from $(1=$ Strongly disagree $)$ to $(5=$ Strongly agree). The statements captured aspects of child development and parenting knowledge ( 9 items, e.g., "Children under the age of 5-years-old are capable of recognizing their emotions"), parent attitudes ( 3 items, e.g., "I feel comfortable talking to other parents about my child's development"), and reading behaviors ( 2 items, e.g., "When I read to my child, I stop to talk to my child about what is happening in the story"). Parents also reported on their reading behavior by answering the question, "How often do you read with your child?" this item was measured on a 5 -point scale $(1=$ Less than once a week, 2 = Once a week, $3=3-5$ times per week, $4=$ Once a day, $5=$ More than once per day). Each questionnaire item was examined as a separate outcome. Because this is a preliminary evaluation, the BCQ was designed to capture the breadth of content presented across program sessions, rather than measure any single dimension of parenting.

Parent modernity. Parents reported on their parenting beliefs using the progressive subscale of the Parental Modernity Scale (Schaefer \& Edgerton, 1985), which measures the degree to which parents endorse child-centered parenting practices. Parents reported on eight items (e.g., "A child's ideas should be seriously considered in making family decisions) on a 5 -point scale ranging from $(1=$ Strongly disagree $)$ to $(5=$ Strongly agree $)$. Higher scores represented stronger endorsement of child-centered beliefs (pre-test $\alpha=.61$, post-test $\alpha=.72$ ).

Parental self-agency. Parents reported on their "confidence in their ability to act successfully in the parental role" (Dumka, Stoerzinger, Jackson, \& Roosa, 1996, p. 221) using the Parenting Self-Agency Measure (Dumka et al., 1996). Parents rated five items (e.g., "I feel I can solve most problems between my children and me.") on a 5-point scale ranging from $(1=$ Almost never or never $)$ to $(5=$ Almost always or always $)$. Higher scores represented higher parental self-agency (pre-test $\alpha=.77$, post-test $\alpha=.78$ ). 
Covariates. To control for other factors that may influence changes in our outcome variables of interest, models controlled for family characteristics and program quality. Specifically, parents reported demographic information including child age and gender, parent age and education level, parent race/ethnic minority status.

Finally, to account for variability of program quality, trained researchers observed and globally rated the overall quality of delivery at each session. Program quality was rated across nine items (e.g., "The instructor was engaging and enthusiastic when presenting the program content" and "The instructor was well-prepared for class and had confidence in delivering the program content"; $\alpha=.77)$ on a 3 -point scale $(1=$ Low, $2=$ Medium, $3=$ High $)$.

\subsection{Analytic Plan}

A repeated measures General Linear Model (GLM) was used to assess change in program outcomes after participants completed Books Can... ${ }^{\circ}$. Models were specified using TYPE $=$ TWOLEVEL to account for the nested nature of the data (i.e., pre- and post-tests nested within individual participants). Each program outcome was modeled individually, with a time variable (pre-test $=0$, post-test $=1$ ) as the Level 1 predictor. Between person covariates were entered at Level 2. Analyses were conducted using Mplus 7.4 (Muthen \& Muthen, 1998-2016) using full information maximum likelihood to handle missing data, which minimizes bias in parameter estimates while retaining the original sample size (Enders, 2013). Fewer families completed the post-survey $(n=67)$ than the pre-survey $(n=103)$; however, $t$-tests and chi-square difference tests indicated no significant demographic differences between families who completed vs. did not complete the post-survey (i.e., child sex, minority status, level of parental education, parent age, child age). Similarly, average course quality did not statistically differ for those who did and did not complete the post-survey.

\section{Results}

First, descriptive statistics and zero-order correlations among study variables and covariates were examined and are presented in Table 1. Next, a two-level GLM was conducted for each outcome to determine whether participants scored differently on the program outcomes after having completed the program compared to before. Results from each model are presented in Table 2. Significant findings in expected directions emerged for seven parenting outcomes. 
Table 1. Descriptive statistics and correlations for study variables (Pre-test $n=99-102$, Post test $\mathrm{n}=66-67$ )

\begin{tabular}{|c|c|c|c|c|c|c|c|c|c|c|c|}
\hline & & & & & & \multicolumn{6}{|c|}{ Between-Person Covariates } \\
\hline & & & & & & $\begin{array}{l}\text { Parent } \\
\text { Education }\end{array}$ & $\begin{array}{l}\text { Child } \\
\text { Sex }^{\mathrm{b}}\end{array}$ & $\begin{array}{l}\text { Minority } \\
\text { Status }^{\mathrm{c}}\end{array}$ & $\begin{array}{l}\text { Course } \\
\text { Quality }\end{array}$ & $\begin{array}{l}\text { Child } \\
\text { Age }\end{array}$ & $\begin{array}{l}\text { Parent } \\
\text { Age }\end{array}$ \\
\hline Outcomes & Time & $M$ & $S D$ & Min & Max & $r$ & $r$ & $r$ & $r$ & $r$ & $r$ \\
\hline \multicolumn{12}{|l|}{ Parent Knowledge } \\
\hline \multirow{2}{*}{$\begin{array}{l}\text { Library } \\
\text { caregiving }\end{array}$} & Pre & 4.42 & .74 & 2 & 5 & -.04 & -.00 & .19 & .04 & .12 & -.08 \\
\hline & Post & 4.43 & .68 & 3 & 5 & -.00 & -.19 & .24 & .00 & -.07 & .08 \\
\hline \multirow{2}{*}{ Books as tool } & Pre & 4.57 & .68 & 1 & 5 & -.14 & -.11 & .03 & -.18 & -.06 & -.13 \\
\hline & Post & 4.73 & .51 & 3 & 5 & .05 & -.15 & .20 & .17 & -.27 & .08 \\
\hline \multirow{2}{*}{$\begin{array}{l}\text { Long-term } \\
\text { impact }\end{array}$} & Pre & 4.61 & .70 & 1 & 6 & -.19 & -.08 & .17 & -.15 & .06 & -.15 \\
\hline & Post & 4.88 & .33 & 4 & 5 & .07 & -.04 & -.14 & .02 & $-.30^{*}$ & .19 \\
\hline \multirow{2}{*}{$\begin{array}{l}\text { My actions don't } \\
\text { matter }^{\mathrm{a}}\end{array}$} & Pre & 2.12 & 1.43 & 1 & 5 & $.22^{*}$ & $.20^{*}$ & .08 & .14 & .22 & -.00 \\
\hline & Post & 1.46 & .86 & 1 & 5 & .02 & .04 & $.28^{*}$ & .10 & $.32^{*}$ & -.17 \\
\hline \multirow{2}{*}{$\begin{array}{l}\text { Attention for no } \\
\text { reason }\end{array}$} & Pre & 2.46 & 1.30 & 1 & 5 & $.29^{* *}$ & .15 & .01 & $.20^{*}$ & .10 & -.04 \\
\hline & Post & 2.39 & 1.10 & 1 & 5 & .13 & .03 & .19 & .21 & .11 & -.12 \\
\hline \multirow{2}{*}{ Model for future } & Pre & 4.43 & .73 & 1 & 5 & $-.25^{*}$ & .03 & -.01 & -.12 & -.06 & -.07 \\
\hline & Post & 4.52 & .73 & 1 & 5 & .04 & .18 & -.25 & -.11 & -.04 & .04 \\
\hline \multirow{2}{*}{$\begin{array}{l}\text { Recognize } \\
\text { emotions }\end{array}$} & Pre & 4.12 & .95 & 1 & 5 & .04 & .13 & $.23^{*}$ & -.04 & -.08 & -.01 \\
\hline & Post & 3.96 & 1.21 & 1 & 5 & $.25^{*}$ & $.31^{*}$ & $.27^{*}$ & -.04 & -.15 & .07 \\
\hline \multirow{2}{*}{$\begin{array}{l}\text { All praise is } \\
\text { equally good }\end{array}$} & Pre & 3.44 & 1.17 & 1 & 5 & $-.25^{*}$ & .10 & .00 & .06 & .16 & .03 \\
\hline & Post & 2.82 & 1.25 & 1 & 5 & -.19 & -.03 & .13 & .09 & .09 & -.02 \\
\hline \multirow{2}{*}{$\begin{array}{l}\text { Can't prevent } \\
\text { behavior }^{\mathrm{a}}\end{array}$} & Pre & 1.94 & 1.09 & 1 & 5 & $-.25^{*}$ & .13 & $.35^{* *}$ & .05 & -.09 & -.08 \\
\hline & Post & 1.79 & .96 & 1 & 5 & -.08 & .06 & .19 & .08 & .14 & -.08 \\
\hline \multicolumn{12}{|l|}{ Parent Attitudes } \\
\hline \multirow{2}{*}{ Talking to parents } & Pre & 4.09 & .81 & 1 & 5 & .04 & .14 & -.08 & -.16 & .07 & -.09 \\
\hline & Post & 4.26 & .69 & 2 & 5 & -.02 & -.05 & .16 & -.10 & -.10 & .10 \\
\hline \multirow{2}{*}{$\begin{array}{l}\text { Interact with } \\
\text { other parents }\end{array}$} & Pre & 3.87 & .97 & 1 & 5 & -.10 & -.01 & -.15 & -.02 & .04 & $-.38^{* *}$ \\
\hline & Post & 4.12 & .86 & 1 & 5 & .20 & .02 & -.13 & -.04 & -.02 & -.17 \\
\hline \multirow{2}{*}{$\begin{array}{l}\text { Deal } \\
\text { outbursts }\end{array}$} & Pre & 3.75 & .91 & 1 & 5 & $-.20^{*}$ & .03 & .03 & .00 & .10 & .03 \\
\hline & Post & 3.94 & .76 & 2 & 5 & -.09 & -.11 & .15 & .12 & .02 & .04 \\
\hline \multirow{2}{*}{ Parent modernity } & Pre & 31.99 & 4.02 & 12 & 40 & .14 & -.12 & -.05 & .01 & .03 & .08 \\
\hline & Post & 32.36 & 3.82 & 23 & 40 & $.28^{*}$ & -.04 & -.18 & .18 & $-.34^{*}$ & .03 \\
\hline \multirow{2}{*}{$\begin{array}{l}\text { Parental self- } \\
\text { agency }\end{array}$} & Pre & 4.05 & .54 & 2.80 & 5 & -.20 & .05 & .09 & -.02 & .19 & -.11 \\
\hline & Post & 4.15 & .51 & 3 & 5 & -.13 & .03 & .08 & -.09 & .09 & .03 \\
\hline \multicolumn{12}{|l|}{ Reading Behavior } \\
\hline \multirow{2}{*}{$\begin{array}{l}\text { Discuss what is } \\
\text { happening }\end{array}$} & Pre & 4.23 & .94 & 2 & 5 & .05 & -.02 & $-.27^{*}$ & -.00 & .04 & .07 \\
\hline & Post & 4.36 & .88 & 1 & 5 & -.12 & -.08 & -.21 & .02 & -.22 & .20 \\
\hline \multirow{6}{*}{$\begin{array}{l}\text { Reading } \\
\text { frequency }\end{array}$} & Pre & 4.28 & .93 & 1 & 5 & .14 & $-.24^{*}$ & $-.30^{* *}$ & .08 & -.20 & -.02 \\
\hline & Post & 4.44 & .75 & 3 & 5 & .01 & -.14 & $-.26^{* *}$ & .20 & $-.31^{*}$ & -.09 \\
\hline & & & & & $M$ & 6.63 & .45 & .31 & 2.73 & 2.33 & 36.09 \\
\hline & & & & & $S D$ & 1.65 & .50 & .46 & .18 & 1.29 & 7.48 \\
\hline & & & & & Min & 1 & 0 & 0 & 2.34 & .25 & 23.51 \\
\hline & & & & & Max & 9 & 1 & 1 & 2.96 & 5.18 & 65.88 \\
\hline
\end{tabular}

Note. ${ }^{a}$ indicates negatively valenced program items, where decreases from pre- to post- test are expected. ${ }^{\mathrm{b}}$ male $=1$, ${ }^{c}$ non-white $=1$

${ }^{+} \mathrm{p}<.10,{ }^{*} \mathrm{p}<.05,{ }^{* *} \mathrm{p}<.01$

\subsection{Parent Knowledge}

For parent knowledge outcomes, three significant results were detected. Specifically, there was a significant increase from pre- to post-test in level of agreement for the item: "Helping my child with social-emotional development now will have a positive impact on their social skills for the rest of their life," whereby, on average, parents demonstrated a .50 standard 
deviation (SD) increase. Further, significant decreases were detected among two negatively worded items: "It doesn't matter how I act, as long as I tell my child how to behave appropriately," and "All types of praise are equally good for my child;" an average .60 SD decrease on the first item, and .80 SD decrease on the second.

\subsection{Parent Attitudes}

For changes in parents' attitudes about parenting - including their perceptions of connectedness, confidence, and preparedness in their role as a parent - significant improvement was detected for the items: "I have regular opportunities to interact with other parents," and, "I feel comfortable talking to other parents about my child's development;" an average $.38 \mathrm{SD}$ increase on the first item, and $.41 \mathrm{SD}$ increase on the second. A significant improvement was also detected for parental self-agency, whereby parents demonstrated a .38 SD increase in self-agency from pre- to post-test.

\subsection{Reading Behaviors}

Regarding parent-child book reading behaviors, frequency of book reading significantly increased from pre- to post-test. At post-test, parents were 1.20 times more likely to read more frequently than at pre-test.

Table 2. Results of two-level general linear models to test for pre-test and post-test differences for participants ( $\mathrm{n}=119)$

\begin{tabular}{|c|c|c|c|c|c|c|c|c|c|c|c|c|c|c|}
\hline \multirow[b]{2}{*}{ Outcomes } & \multicolumn{2}{|c|}{$\begin{array}{l}\text { Time } \\
(\text { post }=1)\end{array}$} & \multicolumn{2}{|c|}{$\begin{array}{l}\text { Parent } \\
\text { Education }\end{array}$} & \multirow{2}{*}{$\begin{array}{l}\begin{array}{l}\text { Child } \\
\text { Sex }^{\mathrm{b}}\end{array} \\
\beta\end{array}$} & \multicolumn{2}{|c|}{$\begin{array}{l}\text { Minority } \\
\text { Status }^{\mathrm{c}}\end{array}$} & \multicolumn{2}{|c|}{$\begin{array}{l}\text { Course } \\
\text { Quality }\end{array}$} & \multicolumn{2}{|c|}{ Child Age } & \multicolumn{2}{|c|}{$\begin{array}{l}\text { Parent } \\
\text { Age }\end{array}$} & \multirow[b]{2}{*}{$S E$} \\
\hline & $\beta$ & $S E$ & $\beta$ & $S E$ & & $S E$ & $\beta$ & $S E$ & $\beta$ & $S E$ & $\beta$ & $S E$ & $\beta$ & \\
\hline \multicolumn{15}{|l|}{ Parent Knowledge } \\
\hline $\begin{array}{ll}\text { Library } & \text { for } \\
\text { caregiving } & \end{array}$ & .01 & .10 & .01 & .03 & -.07 & .12 & $.33^{*}$ & .12 & .03 & .34 & .00 & .06 & .00 & .01 \\
\hline Books as tool & $.16^{+}$ & .09 & -.02 & .03 & -.12 & .11 & .11 & .11 & -.23 & .20 & -.08 & .06 & -.00 & .01 \\
\hline Long-term impact & $.28^{* *}$ & .08 & -.04 & .03 & -.06 & .10 & .09 & .09 & $-.34^{*}$ & .16 & -.03 & .06 & -.00 & .01 \\
\hline $\begin{array}{l}\text { My actions don't } \\
\text { matter }^{\text {a }}\end{array}$ & $-.69^{* *}$ & .16 & $.13^{*}$ & .05 & $.37^{+}$ & .19 & $.38^{+}$ & .20 & $.72^{+}$ & .42 & $.20^{*}$ & .10 & -.01 & .01 \\
\hline $\begin{array}{l}\text { Attention for no } \\
\text { reason }^{\mathrm{a}}\end{array}$ & -.14 & .16 & $.17^{* *}$ & .05 & .30 & .20 & .26 & .22 & $1.22^{*}$ & .50 & .07 & .08 & -.01 & .01 \\
\hline Model for future & .13 & .10 & $-.07^{*}$ & .03 & .13 & .27 & -.17 & .15 & -.34 & .23 & -.02 & .07 & -.00 & .01 \\
\hline $\begin{array}{l}\text { Recognize } \\
\text { emotions }\end{array}$ & -.21 & .16 & .08 & .06 & $.44^{* *}$ & .17 & .15 & .19 & -.11 & .40 & $-.11^{+}$ & .06 & .00 & .01 \\
\hline $\begin{array}{l}\text { All praise is equally } \\
\text { good }^{\text {a }}\end{array}$ & $-.64^{* *}$ & .14 & $-.16^{* *}$ & .06 & .12 & .22 & .05 & .27 & .61 & .58 & .13 & .09 & .00 & .01 \\
\hline $\begin{array}{ll}\text { Can't } & \text { prevent } \\
\text { behavior }^{\mathrm{a}} & \end{array}$ & $-.19^{+}$ & .10 & -.09 & .05 & .27 & .17 & $.69^{* *}$ & .23 & .41 & .36 & -.07 & .08 & -.01 & .01 \\
\hline \multicolumn{15}{|l|}{ Parent Attitudes } \\
\hline Talking to parents & $.21^{*}$ & .09 & .01 & .04 & .12 & .13 & .02 & .16 & -.51 & .37 & .02 & .05 & -.01 & .01 \\
\hline $\begin{array}{l}\text { Interact with other } \\
\text { parents }\end{array}$ & $.26^{*}$ & .11 & -.00 & .05 & .03 & .16 & $-.36^{+}$ & .20 & -.26 & .32 & .04 & .06 & $-.04^{* *}$ & .01 \\
\hline Deal with outbursts & $.20^{+}$ & .10 & $-.10^{*}$ & .04 & .04 & .15 & .06 & .17 & .34 & .35 & .03 & .06 & .01 & .01 \\
\hline Modernity & .04 & .37 & .35 & .25 & -.78 & .76 & -.19 & .83 & .96 & 1.49 & -.18 & .37 & .03 & .04 \\
\hline $\begin{array}{l}\text { Parental } \\
\text { agency }\end{array}$ & $.12^{*}$ & .05 & $-.05^{*}$ & .03 & .09 & .09 & .04 & .11 & -.06 & .23 & .05 & .04 & -.01 & .01 \\
\hline \multicolumn{15}{|l|}{$\begin{array}{l}\text { Reading } \\
\text { Behaviors }\end{array}$} \\
\hline $\begin{array}{l}\text { Discuss what is } \\
\text { happening }\end{array}$ & .15 & .10 & -.03 & .04 & -.10 & .16 & $-.49^{*}$ & .21 & .14 & .32 & .01 & .08 & .01 & .01 \\
\hline $\begin{array}{l}\text { Frequency } \\
\text { reading }\end{array}$ & $.18^{*}$ & .09 & .02 & .05 & $-.36^{*}$ & .16 & $-.57^{* *}$ & .20 & .51 & .32 & -.10 & .08 & -.00 & .01 \\
\hline
\end{tabular}

Note. ${ }^{a}$ indicates negatively valenced program items, where decreases from pre- to post- test are expected.

${ }^{+} \mathrm{p}<.10,{ }^{*} \mathrm{p}<.05,{ }^{* *} \mathrm{p}<.01$

\section{Discussion and Conclusion}

Recent research has highlighted the potential for PLs to promote family engagement in children's learning (Ash \& Meyers, 2009; Meyers \& Henderson, 2007). This is the first study to examine the effectiveness of EST programming focused on promoting children's SE development. The purpose of this study was to investigate whether participating in the Books 
Can... ${ }^{\circ}$ program is related to improvements in parent knowledge, attitudes, and reading behaviors. Using a pre-post design, the study's findings provide initial support for our hypotheses, with significant change detected for outcomes across several important parenting domains.

\subsection{Parent Knowledge}

This study provides initial evidence that the Books Can... ${ }^{\circ}$ program provides new and important information on children's SE development to families. After participating, parents more strongly agreed that helping their children with SE development early on would have a positive impact on their social skills for the rest of their lives. Understanding that emotional development starts early is essential for providing infants with warm, responsive, and consistent caregiving (Dawson, Frey, Panagiotides, Osterling, \& HessI, 1997; Glaser, 2000). Further, how parents respond to and discuss their child's emotions are meaningful socialization strategies that support SE development (Denham, Bassett, \& Wyatt, 2010). During the program families are taught developmentally appropriate expectations for how children express and manage emotions and practical strategies to foster healthy emotional development in their young child (e.g., label emotion expressions in the characters of a book while reading).

The Books Can... ${ }^{\circ}$ program also appeared to teach parents about how children learn to regulate their emotions and behavior from watching their parents (Klinnert, Campos, Sorce, Emde, \& Svejda, 1983). By the end of the program parents more strongly disagreed with the statement that it doesn't matter how I [the parent] act as long as I tell my child how to behave appropriately. This is supported by research demonstrating that young children use their parents as models for how to express emotions (Klinnert et al., 1983). The program explicitly encourages parents to reflect on how they manage their own emotional responses and are taught the importance of remaining calm and coaching children through emotional outbursts, rather than becoming upset when a child misbehaves. Parents also practice practical regulation strategies, such as the use of a calming toy and practicing yoga.

Finally, after participating in Books Can... ${ }^{\circ}$, parents less strongly agreed that all types of praise are equally good for their child. In line with recent research on the quality of praise (e.g., Zentall \& Morris, 2010), Books Can... ${ }^{\circ}$ provides parents with practical tips to maximize the effectiveness of praise through being specific and encouraging effort over desired outcomes.

\subsection{Parent Attitudes}

After participating in the Books Can.. ${ }^{\odot}$ program, parents indicated that they felt more comfortable talking to other parents about their child's development and had increased confidence in their ability to act successfully in the parental role (i.e., parental self-agency). These are promising results, as high parental self-agency can act as a buffer against the development of behavior problems (Lamborn, Mounts, Steinberg, \& Dornbusch, 1991; Pettit \& Bates 1989) and support children's self-esteem, social competence, and academic achievement (Holmbeck et al. 1995; Jones \& Prinz, 2005). Across all six weeks of the Books Can... ${ }^{\odot}$ program, parents are provided with tips and activities for supporting their child's SE development at home. They also gain a deeper understanding of how many everyday interactions promote healthy development. For example, many parents are surprised to learn that taking the time to talk, read, sing, and play with their child everyday promotes SE development.

Further, parents' active involvement in the larger community and especially their involvement in community entities with the capacity to educate children (schools, museums, libraries, etc.) is widely regarded as important for positive child development (Chavkin \& Williams, 1993; Henderson \& Mapp, 2002). After participating in the Books Can... ${ }^{\odot}$ program, parents reported having more regular opportunities to interact with other parents. The Books Can... ${ }^{\odot}$ program promotes these positive changes in parent attitudes both through explicit instruction and structural components. To promote parents' engagement with each other, parents and children are asked to commit to attending all six weeks of the program. Further, interaction with other members of the class is explicitly encouraged and supported during activities. Moreover, because the classes are set in the children's section of the PL (and near a park at the community center), parents often make connections with each other before and after the official class period.

\subsection{Reading Behaviors}

Parents also reported increased frequency of book reading with their child at the end of the program. Because book reading promotes children's cognitive and SE development, as well as literacy development (Bus, Van IJzendoorn, \& Pellegrini, 1995; Neuman, 1996), this is a promising finding. To encourage shared book reading, the program includes many reading activities. For example, instructors read two books aligned with the week's topic and model dialogic book reading for parents whereby the children are prompted to respond to questions about the book (e.g., "How can you tell she is feeling sad?"). Further, families are given a book to take-home and add to their personal collection and are encouraged to check out books from the library after class. 


\subsection{Limitations, Strengths and Future Directions}

Although this study offers important and novel evidence regarding the potential for EST programming in PLs to promote parenting, it is not without limitations. First, the pre-post study design offers preliminary insight into the potential benefits of Books Can... ${ }^{\circ}$ for parent knowledge, attitudes, and behavior. Due to the correlational nature of the study, however, this evaluation was unable to isolate program impact; rather, a more rigorous experimental or quasi-experimental design to evaluate program effectiveness, such as a randomized control trial, is needed. Despite the limitations associated with utilizing a single-sample design with no counterfactual, a strength of the present study was the inclusion of covariates (e.g., parent education, minority status) and sophisticated analytic approach to analyzing the data (i.e., multilevel modeling), the results are stronger than traditional mean comparisons (e.g., t-tests) because the estimates take into account outside factors that may explain parenting outcomes, as well as the non-independent nature of the data.

An additional limitation of the study is the possibility of selection bias. It is notable that most parents who selected into attending this program were frequent library users, and thus, may already have been particularly knowledgeable about their children's early SE development, leaving less room for improvement. Additionally, logistical barriers existed: the program was most frequently offered on weekdays during the day, making the program less accessible to families with more demands (e.g., work). Although efforts were made to encourage a diverse set of families to attend (e.g., Saturday sessions, community center location), it is likely that the parents who attended the six-week program are qualitatively different than parents who do not attend library programming at all. Future work to evaluate the effectiveness of this program would benefit from recruiting a more general community sample - including families who are less familiar with the library setting and program offerings.

Third, this study relies on parent-report whereby parents reflected on their own parenting and child development knowledge. Researchers have highlighted concerns regarding the validity of self-report measures, as they may result in both measurement error and conscious bias (Locke \& Prinz, 2002; Perepletchikova, \& Kazdin, 2004). The program specific items were created by the program evaluators for the current study and may not be generalizable to other EST programs that have different goals. The strength of these items, however, is that they were designed to measure the specific concepts covered in the program curriculum and therefore may be more sensitive to change. Furthermore, the fact that this study also detected significant improvement on parental self- agency (Dumka et al., 1996), a widely used, validated measure, is promising and suggests that the program improved parenting more generally. Future work would benefit from multi-method approaches to assessment of program effects, such as observations of parent-child interactions and direct child assessments, in addition to parent-report of program specific and more general measures of parenting. Finally, it is also important to note that these improvements were detected after only six, once a week session. This represents a relatively modest time commitment for families who attended program sessions regularly; thus, it is promising that a short-, low-dosage intervention showed preliminary evidence of positive change in parents.

\subsection{Conclusion}

This study is the first to document associations between EST programming and changes in parent knowledge, attitudes, and reading behaviors important for supporting children's SE development. Results suggest that by incorporating aspects of parent education into PL storytime programming, community-based settings can support family engagement and support positive parenting practices associated with children's school readiness. Considering that nationally, kindergarten teachers report the majority of their students lack the social and behavioral skills they need to engage in learning (Bernstein et al., 2014), identifying ways in which community settings can support parents of young children is essential. The field would benefit from continued investigation of the effectiveness of EST programs in PLs on parenting using more rigorous methodology (e.g., experimental design) to establish evidence-based practices for libraries across the U.S.

\section{Acknowledgements}

The authors would like to acknowledge The Partnership for Family-Library Engagement with Scottsdale Public Library that has led to advancements in applied developmental research and public library programming, and which continues to influence their work today. This project was supported by Arizona State Library, Archives \& Public Records, a division of the Secretary of State, with federal funds from the Institute of Museum and Library Services.

\section{References}

Arizona Department of Education. (2013). Social emotional standard. In Early learning standards, 3rd edition. Retrieved from https://cms.azed.gov/home/GetDocumentFile?id=58795495aadebe0c98a804fc

Ash, V., \& Meyers, E. (2009). Every child ready to read@ your library. Children and Libraries, 7, 3-7. Retrieved from https://journals.ala.org/index.php/cal/article/viewFile/79/54\#page $=4$

Bernier, A., Carlson, S. M., \& Whipple, N. (2010). From external regulation to self-regulation: Early parenting precursors 
of young children's executive functioning. Child Development, 81, 326-339. https://doi.org/10.1111/j.14678624.2009.01397.x

Bernstein, S., West, J., Newsham, R., \& Reid, M. (2014). Kindergartners' skills at school entry: An analysis of the ECLSK. New York: Mathematic Policy Research.

Bierman, K. L., Nix, R. L., Greenberg, M. T., Blair, C., \& Domitrovich, C. E. (2008). Executive functions and school readiness intervention: Impact, moderation, and mediation in the Head Start REDI program. Development and Psychopathology, 20, 821-843. https://doi.org/10.1017/S0954579408000394

Birch, S. H., \& Ladd, G. W. (1997). The teacher-child relationship and children's early school adjustment. Journal of School Psychology, 35, 61-79. https://doi.org/10.1016/S0022-4405(96)00029-5

Bus, A. G., Van IJzendoorn, M. H., \& Pellegrini, A. D. (1995). Joint book reading makes for success in learning to read: A meta-analysis on intergenerational transmission of literacy. Review of Educational Research, 65, 1-21. https://doi.org/10.2307/1170476

Byington, C. L., Hobson, W. L., Torres-Nielsen, G., Winter, K., Ortiz, K. A., \& Buchi, K. F. (2008). The good habit of reading (el buen habito de la lectura): Parental reactions to an enhanced Reach Out and Read program in a clinic for the underserved. Journal of Health Care for the Poor and Underserved, 19, 363-368.

https://doi.org/10.1353/hpu.0.0024

Callanan, M. A., Castañeda, C. L., Luce, M. R., \& Martin, J. L. (2017). Family science talk in museums: Predicting children's engagement from variations in talk and activity. Child Development, 88, 1492-1504. https://doi.org/10.1111/cdev.12886

Campana, K., Mills, J. E., Capps, J. L., Dresang, E. T., Carlyle, A., Metoyer, C. A., ... Kotrla, B. (2016). Early literacy in library storytimes: A study of measures of effectiveness. The Library Quarterly, 86, 369-388. https://doi.org/10.1086/688028

Chavkin, N. F., \& Williams, D. L. (1993). Minority parents and the elementary school: Attitudes and practices. In N. F. Chavkin (Ed.) Families and Schools in a Pluralistic Society (pp. 73-83). New York: State University of New York Press.

Copple, C., \& Bredekamp, S. (2009). Developmentally appropriate practice in early childhood programs serving children from birth through age 8. National Association for the Education of Young Children. 1313 L Street NW Suite 500, Washington, DC 22205-4101.

Dawson, G., Frey, K., Panagiotides, H., Osterling, J., \& HessI, D. (1997). Infants of depressed mothers exhibit atypical frontal brain activity a replication and extension of previous findings. Journal of Child Psychology and Psychiatry, 38, 179-186. https://doi.org/10.1111/j.1469-7610.1997.tb01852.x

Denham, S. A., Bassett, H. H., \& Wyatt, T. M. (2010). Gender differences in the socialization of preschoolers' emotional competence. In A. Kennedy Root \& S. Denham (Eds.), The role of gender in the socialization of emotion: Key concepts and critical issues. New Directions for Child and Adolescent Development, 128, 29-49. San Francisco: Jossey-Bass. https://doi.org/10.1002/cd.267

Denham, S. A., Blair, K. A., DeMulder, E., Levitas, J., Sawyer, K., Auerbach-Major, S., \& Queenan, P. (2003). Preschool emotional competence: Pathway to social competence. Child Development, 74, 238-256. https://doi.org/10.1111/1467-8624.00533

Denham, S. A., Zahn-Waxler, C., Cummings, E. M., \& Iannotti, R. J. (1991). Social competence in young children's peer relations: Patterns of development and change. Child Psychiatry \& Human Development, 22, 29-44. https://doi.org/10.1007/BF00706057

Dumka, L. E., Stoerzinger, H. D., Jackson, K. M., \& Roosa, M. W. (1996). Examination of the cross-cultural and crosslanguage equivalence of the parenting self-agency measure. Family Relations, 45, 216-222. https://doi.org/10.2307/585293

Enders, C. K. (2013). Dealing with missing data in developmental research. Child Development Perspectives, 7, 27-31. https://doi.org/10.1111/cdep.12008

Feinberg, S., Kuchner, J. F., \& Feldman, S. (1998). Learning environments for young children: Rethinking library spaces and services. Chicago: American Library Association.

First Things First, \& Arizona Department of Education. (n.d.). Arizona's infant and toddler developmental guidelines, 1st edition. Retrieved from https://www.firstthingsfirst.org/Publications/az_infant_toddler_guidelines.pdf 
Glaser, D. (2000). Child abuse and neglect and the brain: A review. The Journal of Child Psychology and Psychiatry and Allied Disciplines, 41, 97-116. https://doi.org/10.1177/1468798415608907

Henderson, A. T., \& Mapp, K. L. (2002). A new wave of evidence: The impact of school, family, and community connections on student achievement. National Center for Family and Community Connections with Schools. Retrieved from http://files.eric.ed.gov/fulltext/ED536946.pdf

Hoff, E., Laursen, B., \& Tardif, T. (2002). Socioeconomic status and parenting. In M. H. Bornstein (Ed.), Handbook of parenting (2nd ed., pp. 231-252). Mahwah, NJ: Erlbaum.

Holmbeck, G. N., Paikoff, R. L., \& Brooks-Gunn, J. (1995). Parenting adolescents. In M. H. Bornstein (Ed.), Handbook of parenting (pp. 91-118). Hillsdale, NJ: Lawrence Erlbaum Associates.

Institute of Museum and Library Services (IMLS; 2013). Growing young minds: How libraries and museums create lifelong learners. Retrieved from https://www.imls.gov/assets/1/

Johnson, C., Ironsmith, M., Snow, C. W., \& Poteat, G. M. (2000). Peer acceptance and social adjustment in preschool and kindergarten. Early Childhood Education Journal, 27(4), 207-212. https://doi.org/10.1023/B:ECEJ.0000003356.30481.7a

Jones, T. L., \& Prinz, R. J. (2005). Potential roles of parental self-efficacy in parent and child adjustment: A review. Clinical psychology review, 25(3), 341-363. https://doi.org/10.1016/j.cpr.2004.12.004

Kaminski, J. W., Valle, L. A., Filene, J. H., \& Boyle, C. L. (2008). A meta-analytic review of components associated with parent training program effectiveness. Journal of Abnormal Child Psychology, 36, 567-589. https://doi.org/10.1007/s10802-007-9201-9

Klinnert, M. D., Campos, J., Sorce, J. F., Emde, R. N., \& Svejda, M. J. (1983). Social referencing: Emotional expressions as behavior regulators. Emotion: Theory, Research, and Experience, 2, 57-86. https://doi.org/10.1016/B978-0-12558702-0.50009-1

Laible, D. (2004). Mother-child discourse in two contexts: Links with child temperament, attachment security, and socioemotional competence. Developmental Psychology, 40, 979-992. https://doi.org/10.1037/0012-1649.40.6.979

Lamborn, S. D., Mounts, N. S., Steinberg, L., \& Dornbusch, S. M. (1991). Patterns of competence and adjustment among adolescents from authoritative, authoritarian, indulgent, and neglectful families. Child development, 62(5), 10491065. https://doi.org/10.1111/j.1467-8624.1991.tb01588.x

Lerner, C., \& Nightingale, M. O. (2016). Tuning In: Parents of Young Children Speak up about What They Think, Know, and Need. ZERO TO THREE, 37(1), 44-49. Retrieved from file://Users/melizable/Downloads/National\%20Parent\%20Survey\%20Report\%20(1).pdf

Locke, L. M., \& Prinz, R. J. (2002). Measurement of parental discipline and nurturance. Clinical Psychology Review, 22, 895-929. https://doi.org/10.1016/S0272-7358(02)00133-2

Lopez, M. E., Caspe, M., \& McWilliams, L. (2016). Public libraries: A vital space for family engagement. Cambridge, MA: Harvard Family Research Project. Retrieved from www.hfrp.org/librarycta.

Meyers, E. \& Henderson, H. (2007). Overview of Every Child Ready to Read @ your library®. Oregon State Library. Retrieved from http://www.oregon.gov/OSL/LD/youthsvcs/reading.healthy.families/rfhf.manual/tab3.ecrr.pdf?ga=t

Morris, A. S., Robinson, L. R., Hays-Grudo, J., Claussen, A. H., Hartwig, S. A., \& Treat, A. E. (2017). Targeting parenting in early childhood: A public health approach to improve outcomes for children living in poverty. Child Development, 88(2), 388-397. https://doi.org/10.1111/cdev.12743

Muthén, L. K., \& Muthén, B. O. (2012). Mplus Version 7 user's guide. Los Angeles, CA: Muthén \& Muthén.

Neuman, S. B. (1996). Children engaging in storybook reading: The influence of access to print resources, opportunity, and parental interaction. Early Childhood Research Quarterly, 11(4), 495-513. https://doi.org/10.1016/S08852006(96)90019-8

Perepletchikova, F., \& Kazdin, A. (2004). Assessment of parenting practices related to conduct problems: Development and validation of the Management of Children's Behavior Scale. Journal of Child and Family Studies, 13, 385-403. https://doi.org/10.1023/B:JCFS.0000044723.45902.70

Pettit, G. S., \& Bates, J. E. (1989). Family interaction patterns and children's behavior problems from infancy to 4 years. Developmental Psychology, 25, 413-420. https://doi.org/10.1037/0012-1649.25.3.413

Raver, C. C. (2004). Placing emotional self-regulation in sociocultural and socioeconomic contexts. Child Development, 75, 346-353. https://doi.org/10.1111/j.1467-8624.2004.00676.x 
Robins, L. N., \& Rutter, M. (Eds.). (1990). Straight and devious pathways from childhood to adulthood. Cambridge, NY: Cambridge University Press.

Schaefer, E. S., \& Edgerton, M. (1985). Parental modernity scale of child rearing and educational beliefs.

Stewart, R. A., Bailey-White, S., Shaw, S., Compton, E., \& Ghoting, S. (2014). Enhanced storytimes: Effects on parent/caregiver knowledge, motivation, and behaviors. Children and Libraries, 12(2), 9-14. https://doi.org/10.5860/cal.12n2.09

Taylor, Pratt, van Huisstede, \& Gaias (2016). Measuring for success: An evaluation report. The LINK Enterprise, Arizona State University, Tempe, AZ.

Trentacosta, C. J., \& Izard, C. E. (2007). Kindergarten children's emotion competence as a predictor of their academic competence in first grade. Emotion, 7, 77-88. https://doi.org/10.1037/1528-3542.7.1.77

Valiente, C., Eisenberg, N., Haugen, R., Spinrad, T. L., Hofer, C., Liew, J., \& Kupfer, A. (2011). Children's effortful control and academic achievement: Mediation through social functioning. Early Education and Development, 22, 411-433. https://doi.org/10.1080/10409289.2010.505259

Webster-Stratton, C., Reid, M. J., \& Hammond, M. (2004). Treating children with early-onset conduct problems: Intervention outcomes for parent, child, and teacher training. Journal of Clinical Child and Adolescent Psychology, 33, 105-124. https://doi.org/10.1207/S15374424JCCP3301_11

Webster-Stratton, C., Reid, M., \& Stoolmiller, M. (2008). Preventing conduct problems and improving school readiness: evaluation of the incredible years teacher and child training programs in high-risk schools. Journal of child psychology and psychiatry, 49, 471-488. https://doi.org/10.1111/j.1469-7610.2007.01861.x

Zentall, S. R., \& Morris, B. J. (2010). “Good job, you're so smart”: The effects of inconsistency of praise type on young children's motivation. Journal of experimental child psychology, 107(2), 155-163. https://doi.org/10.1016/j.jecp.2010.04.015

Zins, J. E., Bloodworth, M. R., Weissberg, R. P., \& Walberg, H. (2004). The scientific base linking social and emotional learning to school success. In J. E. Zins, R. P. Weissberg, M. C. Wang, \& H. J. Walberg (Eds.), Building academic success on social and emotional learning: What does the research say? New York: Teachers College Press.

\section{Copyrights}

Copyright for this article is retained by the author(s), with first publication rights granted to the journal.

This is an open-access article distributed under the terms and conditions of the Creative Commons Attribution license which permits unrestricted use, distribution, and reproduction in any medium, provided the original work is properly cited. 